\title{
Screening Selected Linseed (Linum usitatissimum L.) Genotypes for Yield Performance in Sindh, Pakistan
}

\author{
Shoaib Gul1, Asghar Ali Rajper1, Fahad Ali Kalhoro'1, Shamir Ali Kalhoro ${ }^{2,3}$, Amjad Ali", \\ Fayaz Ali Shah ${ }^{5}$, Sajjad Raza ${ }^{4}$, Muneer Ahmed ${ }^{4}$ \\ ${ }^{1}$ Department of Plant Breeding and Genetics, Sindh Agriculture University, Tando Jam, Pakistan \\ ${ }^{2}$ Faculty of Agriculture, Lasbela University of Agriculture, Water \& Marine Sciences, Lasbela, Pakistan \\ ${ }^{3}$ Institute of Soil and Water Conservation, Northwest A\&F University, Yangling, China \\ ${ }^{4}$ College of Natural Resources and Environment, Northwest A\&F University, Yangling, China \\ ${ }^{5}$ Agriculture Research Institute, Tarnab, Peshawar, Pakistan \\ Email: shahmirali.agric@luawms.edu.pk
}

Received 13 December 2015; accepted 13 February 2016; published 16 February 2016

Copyright (C) 2016 by authors and Scientific Research Publishing Inc.

This work is licensed under the Creative Commons Attribution International License (CC BY).

http://creativecommons.org/licenses/by/4.0/

(c) (i) Open Access

\section{Abstract}

The present study was carried out during the year 2013-14 on the screening of the selected linseed genotypes for yield performance in Sindh, Pakistan. The experiment was laid out at the experimental fields of Oilseeds Section, Agriculture Research Institute, Tandojam in a three replicated randomized complete block design. Twelve linseed genotypes (L-53, C-W-2, Shikarpur 2, $P^{-1}$ 6-4, L-8, 11-106, Hala 3, $L^{-1}$, Santane, Summit, $L^{-1} 0$ and check llsi 90 ) were screened for their agronomic performance and correlations amongst yield and its contributing traits were calculated. The analysis of variance suggested significant $(P<0.05)$ variation among linseed genotypes for all the traits studied in this experiment. Most of the genotypes attained flowering and maturity earlier than the check variety; while $\mathbf{P}^{-16} \mathbf{- 4}$ surpassed Ilsi-90 for primary branches; and most of the remaining genotypes were at par with the commercial check for primary branches. Genotype $\mathrm{L}^{-10}$ surpassed the commercial check for capsules plant ${ }^{-1}$ and L-8 was at par with the commercial check; while none of the genotypes could surpass commercial check variety for seed index, but 11-106, Hala-3 and Summit also showed promising performance regarding the seed index. All the

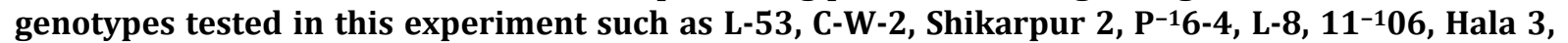
$L^{-17}$, Santane, Summit, $\mathbf{L}^{-1} 0$ surpassed the commercial check variety Ilsi-90 for seed yield plot $^{-1}$. The correlation coefficient for yield and its contributing traits of linseed genotypes showed a positive and significant $(P<0.05)$ association for primary branches plant ${ }^{-1}$ vs seed yield plant $^{-1}$ $\left(r=0.3334^{*}\right)$, days to maturity vs spike length $\left(r=0.5384^{* *}\right)$, days to $75 \%$ flowering vs days to $90 \%$ maturity $\left(r=0.4073^{* *}\right)$, days to $75 \%$ flowering vs seed index $\left(r=0.4291^{* *}\right)$, days to $90 \%$ maturity vs seed index $\left(r=0.3973^{* *}\right.$ and seed index v/s seed yield $\operatorname{plot}^{-1}\left(r=0.5160^{* *}\right)$. Negative and sig- 


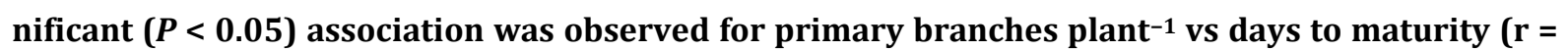
$\left.-0.368^{*}\right)$, capsules plant ${ }^{-1}$ vs days to maturity $\left(r=-0.3567^{*}\right)$, days to $90 \%$ maturity vs seed yield $\operatorname{plant}^{-1}\left(r=-0.4156^{* *}\right)$ and days to $90 \%$ maturity vs seed yield $\operatorname{plot}^{-1}\left(r=-0.3423^{*}\right)$. The new genotypes possess the potential to become future varieties for general cultivation in Sindh province.

\section{Keywords}

\section{Selected Linseed}

\section{Introduction}

Linseed or Flax (Linum usitatissimum L.) is a conventional oilseed as well as a fiber crop and belongs to Linaceae family with chromosome number 30. Linseed oil is colorless to yellowish and obtained from the dried ripe seeds of linseed. It is native to the region extending from the eastern Mediterranean to sub-continent and was probably first domesticated in the Fertile Crescent. Linseed was extensively cultivated in ancient Ethiopia and ancient Egypt. A discovery reported in 2009 of spun, dyed, and knotted wild linseed fibers in a prehistoric cave in the Republic of Georgia shows that the plant was already in use by humans at the surprisingly early date of

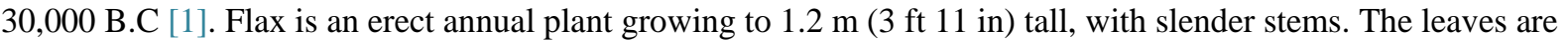
glaucous green, slender lanceolate, 20 - $40 \mathrm{~mm}$ long and $3 \mathrm{~mm}$ broad. The flowers are pure pale blue, 15 - 25 $\mathrm{mm}$ diameter, with five petals; they can also be bright red. The fruit is a round, dry capsule 5 - $9 \mathrm{~mm}$ diameter, containing several glossy brown seeds shaped like an apple pip, 4 - $7 \mathrm{~mm}$ long [2]. Its fiber is used in the manufacturing of canvas, cloth, water resistant pipes, paper and strawboard. Linseed oil is used in the manufacturing of paints and varnish, oil cloth and linoleum [3].

In Pakistan, seed flaxes are cultivated for seed purposes from which oil is extracted. The material remaining after extraction of fibre can be pulped for use in the manufacture of paper and straw board. Linseed oil is used in paints, varnishes and cloth and linoleum. Its by-product oil cake or meal is used as cattle feed and as manure for giving prolonged fertility to soil. Linseed contains $32 \%$ - 34\% oil in seed and good quality fibre extracted from the straw. Linseed has got a great economic value for the commercial utility of its oil and fibres. Linseed has numerous medicinal uses. Its oil is used in local medicines as demulcent, emollient and laxative and is taken orally in bronchial infection and diarrheal. It is also used commercially in soap factories [4].

Genetic diversity is the pre-requisite for genetic improvement of any crop. The progress in developing a superior variety depends largely on the genetic basis of selection of diverse parents and the breeding approach. The progress in breeding for such characters is determined by the magnitude and nature of interactions between their genotypic and phenotypic variability under varying conditions of soil and climate. Hence partitioning the overall variability into its heritable and non-heritable components with the help of genetic parameters such as genetic co-efficient of variation, heritability and genetic advance constitutes an important step in plant breeding programme. For a rational approach towards the improvement of seed yield, selection has to be made for the components of yield. However, the heritable variation is often masked by non-heritable variation, which creates difficulty in selection programme. This suggests the need for partitioning the overall variability into heritable and non-heritable components, which enables the breeder to evolve suitable breeding procedures. The present study was carried out on the screening selected linseed genotype for yield performance.

\section{Materials \& Methods}

The present study was conducted during the year 2013-14 on the screening of the selected linseed genotypes for yield performance. The experiment was laid out at the experimental fields of Oilseeds Section, Agriculture Research Institute, Tando Jam in a three replicated Randomized Complete Block design. The experimental material comprised of 11 new linseed genotypes and a commercial check. The seeds were sown by drill method, keeping plant to plant and row to row spacing of 20 and $30 \mathrm{~cm}$, respectively. The observations were recorded by labelling normal looking five plants at random in each replication for all the genotypes evaluated. 
Varieties:

\begin{tabular}{lll}
\hline 1. L-53 & $5 . \mathrm{L}-8$ & 9. Santane \\
2. C-W-2 & $6.11^{-1} 06$ & 10. Summit \\
3. Shikarpur 2 & 7. Hala 3 & 11. $\mathrm{L}^{-1} 0$ \\
4. $\mathrm{P}^{-1} 6-4$ & $8 . \mathrm{L}^{-1} 7$ & 12. llsi 90 \\
\hline
\end{tabular}

The experimental crop was well grown and thinned to maintain the recommended spacing between plants. The chemical fertilizers and irrigations were applied as per recommended doses of oilseeds. All the recommended cultural practices were carried out at appropriate time. The data were recorded as per the following procedures.

\subsection{Days to $75 \%$ Flowering}

The number of days from sowing to $75 \%$ flowering was counted on the basis of sowing date.

\subsection{Days to $90 \%$ Maturity}

The number of days from sowing to $90 \%$ maturity was counted on the basis of sowing date by visual observation.

\subsection{Plant Height (cm)}

At the time of maturity the height of each selected plant was measured in centimetres from the surface of soil and average of all the selected plants was calculated.

\subsection{Number of Primary Branches Plant ${ }^{-1}$}

The numbers of primary branches produced by each selected plant were counted and replication wise data were recorded on average plant basis.

\subsection{Number of Seeds Capsule ${ }^{-1}$}

The main spike or primary tiller of each selected plant was threshed separately, number of grains was counted and replication wise data were recorded.

\subsection{Number of Capsules Plant ${ }^{-1}$}

The number of capsules on each selected plants were counted and the data were recorded as capsules plant ${ }^{-1}$.

\subsection{Seed Index (1000 Seed Weight in g)}

1000 seeds were randomly taken from the seed lots of each plot and weighed in grams on electric balance in laboratory.

\subsection{Seed Yield Plant $^{-1}(\mathrm{~g})$}

After harvesting, each selected plant was threshed manually and cleaned in the laboratory. The seeds were weighed on electric balance and yield plant ${ }^{-1}$ was recorded in grams.

\subsection{Seed Yield Plot $^{-1}(\mathrm{~kg})$}

After harvesting the experimental crop, the bundles were separately tied for each plot and threshing was done. The seed yield achieved from each plot was separately weighed and kilograms.

\subsection{Correlation Coefficient}

The data thus collected were subjected to analysis through Software SXW Package. The analysis of variance 
(ANOVA) was determined as suggested by Gomez and Gomez [5] and correlation was calculated according to [6], Correlation coefficients were worked out between the following character combinations:

Simple correlation coefficients $(r)$ were calculated after [7], by using the following formula.

$$
\begin{gathered}
\text { Correlation Coefficient }(r)=\frac{\text { Co-variance }}{\text { Geometric mean of covariance }}=\frac{\sum x y}{\sqrt{\left(\sum x\right)^{2}\left(\sum y\right)^{2}}} \\
\sum x y=\sum X Y-\frac{\left(\sum X\right)\left(\sum Y\right)}{N} \\
\sum x^{2}=\sum X^{2}-\frac{\left(\sum X\right)^{2}}{N} \\
\sum y^{2}=\sum Y^{2}-\frac{\left(\sum Y\right)^{2}}{N}
\end{gathered}
$$

where:

$$
\begin{aligned}
& X=\text { Independent variable } \\
& Y=\text { Dependent variable } \\
& N=\text { Number of observations recorded }
\end{aligned}
$$

\section{Results and Discussion}

The present study was carried out during the year 2013-14 on the screening of the selected linseed genotypes for yield performance and associations were calculated amongst yield and its contributing traits. The experimental material comprised of eleven new linseed genotypes and a commercial check (Ilsi). The linseed genotypes included: L-53, C-W-2, Shikarpur 2, $\mathrm{P}^{-1} 6-4, \mathrm{~L}-8,11^{-1} 06$, Hala 3, $\mathrm{L}^{-1} 7$, Santane, Summit, $\mathrm{L}^{-1} 0$ and Ilsi 90 (Check).

The mean squares drawn from the analysis of variance for the traits days to $75 \%$ flowering, days to $90 \%$ maturity, plant height, primary branches plant ${ }^{-1}$ and seeds capsule ${ }^{-1}$ are shown in Table 1 , while the mean squares for the traits capsules plant ${ }^{-1}, 1000$ seed weight, seed yield plant ${ }^{-1}$, seed yield plot $^{-1}$ are given in Table 2 .

The performance of wheat genotypes with regards to days to $75 \%$ flowering, days to $90 \%$ maturity, plant height (cm), primary branches plant ${ }^{-1}$ and seeds capsule ${ }^{-1}$ is given in Table 3; while the data for traits like capsules plant ${ }^{-1}, 1000$ Seed weight $(\mathrm{g})$, seed yield plant ${ }^{-1}(\mathrm{~g})$, seed yield plot $^{-1}$ (g) are presented in Table 4. The correlation coefficients (r) amongst the traits studied for various traits are presented in Table 5 , respectively.

Table 1. Mean squares from analysis of variances for days to $75 \%$ flowering, plant height (cm), days to $90 \%$ maturity, primary branches plant ${ }^{-1}$ and seeds capsule ${ }^{-1}$.

\begin{tabular}{ccccccc}
\hline Source of Variation & $\begin{array}{c}\text { Degrees of } \\
\text { freedom }\end{array}$ & $\begin{array}{c}\text { Days to 75\% } \\
\text { flowering }\end{array}$ & $\begin{array}{c}\text { Plant } \\
\text { height }\end{array}$ & $\begin{array}{c}\text { Days to 90\% } \\
\text { maturity }\end{array}$ & $\begin{array}{c}\text { No. of primary } \\
\text { branches plant }^{-1}\end{array}$ & $\begin{array}{c}\text { No. of seeds } \\
\text { capsule }^{-1}\end{array}$ \\
\hline Replications & 2 & 1.262 & 4.205 & 1.730 & 5.537 & 0.006 \\
Genotypes & 11 & $6.178^{* *}$ & $42.652^{* *}$ & $14.895^{* *}$ & $16.342^{* *}$ & $0.757^{* *}$ \\
Error & 22 & 1.222 & 12.610 & 3.592 & 2.175 & 0.043 \\
\hline
\end{tabular}

${ }^{* *}$ Significant at $1 \%$ probability level.

Table 2. Mean squares from analysis of variances for capsules plant ${ }^{-1}$, seed index (1000 seeds weight), seed yield plant ${ }^{-1}$, seed yield plot ${ }^{-1}$.

\begin{tabular}{cccccc}
\hline Source of Variation & Degrees of freedom & Capsules plant $^{-1}$ & Seed index (1000 seeds weight) & Seed yield plant ${ }^{-1}$ Seed yield plot $^{-1}$ \\
\hline Replications & 2 & 1.258 & 0.001 & 0.003 & 0.0001 \\
Genotypes & 11 & $135.218^{* *}$ & $0.143^{* *}$ & $0.303^{* *}$ & $0.0212^{* *}$ \\
Error & 22 & 2.763 & 0.005 & 0.004 & 0.0010 \\
\hline
\end{tabular}

${ }^{* *}$ Significant at $1 \%$ probability level. 
Table 3. Mean values for agronomic performance of linseed genotypes for days to $75 \%$ flowering, plant height (cm), days to $90 \%$ maturity, primary branches plant ${ }^{-1}$ and seeds capsule ${ }^{-1}$.

\begin{tabular}{|c|c|c|c|c|c|}
\hline Genotypes & Days to $75 \%$ flowering & Plant height & $\begin{array}{l}\text { Days to } 90 \% \\
\text { maturity }\end{array}$ & $\begin{array}{l}\text { No. of primary } \\
\text { branches plant }{ }^{-1}\end{array}$ & $\begin{array}{l}\text { No. of seeds } \\
\text { capsule }^{-1}\end{array}$ \\
\hline $\mathrm{V} 1=\mathrm{L}-53$ & $77.84 \mathrm{c}$ & $61.30 \mathrm{~b}$ & $112.27 \mathrm{~b}$ & $29.66 \mathrm{~b}$ & $9.58 \mathrm{a}$ \\
\hline $\mathrm{V} 2=\mathrm{C}-\mathrm{W}-2$ & $80.78 \mathrm{~b}$ & $62.01 \mathrm{~b}$ & $113.60 \mathrm{~b}$ & $29.67 \mathrm{~b}$ & $8.20 \mathrm{~d}$ \\
\hline V3 = Shikarpur 2 & 81.79 a & $62.88 \mathrm{~b}$ & 117.53 a & $23.07 \mathrm{c}$ & $8.45 \mathrm{c}$ \\
\hline $\mathrm{V} 4=\mathrm{P}-16-4$ & 82.31 a & $61.98 \mathrm{~b}$ & $113.57 \mathrm{~b}$ & 33.00 a & $8.84 \mathrm{~b}$ \\
\hline $\mathrm{V} 5=\mathrm{L}-8$ & 83.10 a & $61.95 \mathrm{~b}$ & $114.57 \mathrm{~b}$ & 30.80 a & $9.67 \mathrm{a}$ \\
\hline $\mathrm{V} 6=11-106$ & 82.42 a & $61.30 \mathrm{~b}$ & $118.10 \mathrm{a}$ & $29.40 \mathrm{~b}$ & $8.47 \mathrm{c}$ \\
\hline V7 = Hala 3 & $80.93 \mathrm{~b}$ & $58.53 \mathrm{~b}$ & $114.27 \mathrm{~b}$ & $30.13 \mathrm{~b}$ & $9.51 \mathrm{a}$ \\
\hline $\mathrm{V} 8=\mathrm{L}-17$ & 82.52 a & 67.08 a & $112.67 \mathrm{~b}$ & $30.33 \mathrm{~b}$ & $8.42 \mathrm{c}$ \\
\hline V9 = Santane & 82.69 a & 71.88 a & 117.90 a & 30.86 a & 8.62 c \\
\hline V10 = Summit & 82.79 a & 68.93 a & $114.73 \mathrm{~b}$ & 30.67 a & $8.84 \mathrm{~b}$ \\
\hline $\mathrm{V} 11=\mathrm{L}-10$ & 82.49 a & $62.24 \mathrm{~b}$ & $112.77 \mathrm{~b}$ & $30.00 \mathrm{~b}$ & $9.15 \mathrm{~b}$ \\
\hline V12 = llsi 90 & 81.44 a & $62.77 \mathrm{~b}$ & $117.73 \mathrm{a}$ & 30.73 a & 8.55 c \\
\hline LSD 0.05 & 1.8724 & 6.0131 & 3.2095 & 2.4975 & 0.3535 \\
\hline
\end{tabular}

Means followed by similar alphabetic letters are not significantly different from each other according to DMR test.

Table 4. Mean values for agronomic performance of linseed genotypes for capsules plant ${ }^{-1}$, seed index (1000 seeds weight), seed yield plant ${ }^{-1}$, seed yield plot $^{-1}$.

\begin{tabular}{|c|c|c|c|c|}
\hline Genotypes & Capsules plant $^{-1}$ & Seed index (1000 seeds weight) & Seed yield plant ${ }^{-1}$ & Seed yield plot ${ }^{-1}$ \\
\hline $\mathrm{V} 1=\mathrm{L}-53$ & $205.40 \mathrm{~d}$ & $4.57 \mathrm{~d}$ & $1.26 \mathrm{a}$ & $0.61 \mathrm{c}$ \\
\hline $\mathrm{V} 2=\mathrm{C}-\mathrm{W}-2$ & $201.53 \mathrm{e}$ & $4.63 \mathrm{~d}$ & $0.63 \mathrm{c}$ & $0.72 \mathrm{~b}$ \\
\hline V3 = Shikarpur 2 & $204.13 d$ & $4.84 \mathrm{c}$ & $0.58 \mathrm{c}$ & $0.68 \mathrm{~b}$ \\
\hline $\mathrm{V} 4=\mathrm{P}-16-4$ & $196.27 \mathrm{f}$ & $5.16 \mathrm{a}$ & $1.28 \mathrm{a}$ & $0.61 \mathrm{c}$ \\
\hline $\mathrm{V} 5=\mathrm{L}-8$ & $212.27 \mathrm{~b}$ & $4.97 \mathrm{~b}$ & $0.72 \mathrm{~b}$ & $0.65 \mathrm{c}$ \\
\hline $\mathrm{V} 6=11-106$ & 207.93 c & $5.14 \mathrm{a}$ & $0.48 \mathrm{~d}$ & $0.56 \mathrm{~d}$ \\
\hline V7 = Hala 3 & 209.87 c & $5.11 \mathrm{a}$ & $1.27 \mathrm{a}$ & $0.55 \mathrm{~d}$ \\
\hline $\mathrm{V} 8=\mathrm{L}-17$ & 207.33 c & $4.66 \mathrm{~d}$ & $0.68 \mathrm{~b}$ & $0.64 \mathrm{c}$ \\
\hline V9 = Santane & 200.93 e & $4.89 \mathrm{~b}$ & $0.60 \mathrm{c}$ & $0.63 \mathrm{c}$ \\
\hline V10 = Summit & 201.73 e & $5.14 \mathrm{a}$ & $1.28 \mathrm{a}$ & $0.57 \mathrm{~d}$ \\
\hline $\mathrm{V} 11=\mathrm{L}-10$ & $221.07 \mathrm{a}$ & $4.92 \mathrm{~b}$ & $0.76 \mathrm{~b}$ & $0.81 \mathrm{a}$ \\
\hline V12 = llsi 90 & $213.40 \mathrm{~b}$ & $5.16 \mathrm{a}$ & $0.71 \mathrm{~b}$ & $0.50 \mathrm{e}$ \\
\hline LSD 0.05 & 2.8148 & 0.1256 & 0.1098 & 0.0536 \\
\hline
\end{tabular}

Means followed by similar alphabetic letters are not significantly different from each other according to DMR test. 
Table 5. Correlation (r) coefficients among various traits in linseed genotypes.

\begin{tabular}{|c|c|c|c|c|c|c|c|c|}
\hline Character & Plant height & $\begin{array}{c}\text { Primary } \\
\text { branches plant }^{-1}\end{array}$ & $\begin{array}{l}\text { Capsules } \\
\text { plant }^{-1}\end{array}$ & $\begin{array}{c}\text { Seeds } \\
\text { capsule }^{-1}\end{array}$ & $\begin{array}{c}\text { Days to } 75 \% \\
\text { flowering }\end{array}$ & $\begin{array}{c}\text { Days to } 90 \% \\
\text { maturity }\end{array}$ & $\begin{array}{l}\text { Seed } \\
\text { Index }\end{array}$ & $\begin{array}{l}\text { Seed yield } \\
\text { plant }^{-1}\end{array}$ \\
\hline Primary branches & $0.1164^{\mathrm{NS}}$ & & & & & & & \\
\hline Capsules plant $^{-1}$ & $-0.2587^{\mathrm{NS}}$ & $-0.0356^{\mathrm{NS}}$ & & & & & & \\
\hline Seeds capsule $e^{-1}$ & $0.2804^{\mathrm{NS}}$ & $0.2087^{\mathrm{NS}}$ & $0.0304^{\mathrm{NS}}$ & & & & & \\
\hline Days to flowering & $0.3093^{\mathrm{NS}}$ & $0.0490^{\mathrm{NS}}$ & $0.0451^{\mathrm{NS}}$ & $-0.2795^{\mathrm{NS}}$ & & & & \\
\hline Days to maturity & $0.1248^{\mathrm{NS}}$ & $-0.3680^{*}$ & $-0.0833^{\mathrm{NS}}$ & $-0.3567^{*}$ & $0.4073^{* *}$ & & & \\
\hline Seed Index & $-0.0628^{\mathrm{NS}}$ & $0.2744^{\mathrm{NS}}$ & $0.0747^{\mathrm{NS}}$ & $0.0609^{\mathrm{NS}}$ & $0.4291^{* *}$ & $0.3973^{* *}$ & & \\
\hline Yield plant ${ }^{-1}$ & $-0.1353^{\mathrm{NS}}$ & $0.3334^{*}$ & $-0.2605^{\mathrm{NS}}$ & $0.5384^{* *}$ & $0.3076^{*}$ & $-0.4156^{* *}$ & $0.1837^{\mathrm{NS}}$ & \\
\hline Yield plot ${ }^{-1}$ & $-0.0001^{\mathrm{NS}}$ & $0.2428^{\mathrm{NS}}$ & $0.2110^{\mathrm{NS}}$ & $0.0065^{\mathrm{NS}}$ & $0.0949^{\mathrm{NS}}$ & $-0.3423^{*}$ & $0.5160^{* *}$ & $0.2890^{\mathrm{NS}}$ \\
\hline
\end{tabular}

The mean squares with regards to linseed yield and its contributing traits of various genotypes (Table 1 and Table 2) showed that all the genotypes differed significantly $(P<0.05)$ from each other for their growth and yield traits such as: days to $75 \%$ flowering, days to $90 \%$ maturity, plant height, primary branches plant ${ }^{-1}$, seeds capsule $^{-1}$, capsules plant ${ }^{-1}, 1000$ seed weight, seed yield plant ${ }^{-1}$ and seed yield plot $^{-1}$. This significance in variation in the growth and yield traits of different wheat genotypes might be associated with genetic makeup of their parental materials.

\subsection{Growth and Yield Performance of Tested Genotypes}

The data with regards to days to $75 \%$ flowering, days to $90 \%$ maturity, plant height, primary branches plant ${ }^{-1}$ and seeds capsule ${ }^{-1}$ (Table 3) indicated that linseed genotype L-8 took maximum days to $75 \%$ flowering (83.10); while the genotype L-53 took minimum days to $75 \%$ flowering (77.84) against 81.44 days to $75 \%$ flowering taken by genotype commercial check variety Ilsi-90. Most of the genotypes surpassed commercial check and took more days to $75 \%$ flowering. The plants of maximum height $(71.88 \mathrm{~cm})$ were observed in genotype Santane and the minimum plant height $(58.53 \mathrm{~cm})$ was noted in the genotype Hala-3 against $62.77 \mathrm{~cm}$ average plant height in commercial check variety Ilsi-90. Genotypes Santane, Summit, $\mathrm{L}^{-1} 7$ and Shikarpur-2 surpassed check variety for this trait.

The linseed genotype $11^{-1} 06$ took more days to reach $90 \%$ maturity (118.10) and the early maturity in 112.27 days was observed in genotype L-53 against the maturity in 117.73 days in case of commercial check Ilsi-90. Most of the genotypes attained maturity earlier than the check variety. Similarly, the number of primary branches plant ${ }^{-1}$ was highest (33.00) in linseed genotype $\mathrm{P}^{-1} 6-4$ and the lowest number of branches plant ${ }^{-1}$ (23.07) was observed in the linseed genotype Shikarpur-2 against 30.73 branches plant $^{-1}$ in commercial check Ilsi-90. Linseed genotype $\mathrm{P}^{-1} 6-4$ surpassed commercial check in primary branches; while most of the remaining genotypes were at par with the commercial check for this trait. Greater number of seeds capsule ${ }^{-1}$ was observed in linseed genotypes L-8 (9.67), L-53 (9.58), Hala-3 (9.51) and $\mathrm{L}^{-1} 0$ (9.15); while the lowest number of seeds capsule $^{-1}$ was observed in the genotype C-W-2 (8.20) against 8.55 seeds capsule ${ }^{-1}$ in commercial check Ilsi-90. Most of the genotypes either exceeded or surpassed the commercial check for this trait.

The genotypic performance in respect of capsules plant ${ }^{-1}$, 1000 seed weight, seed yield plant ${ }^{-1}$, seed yield plot $^{-1}$ (Table 4) showed that the number of capsules plant ${ }^{-1}$ was highest (221.07) in genotype $\mathrm{L}^{-1} 0$ and the lowest number of capsules plant ${ }^{-1}(196.27)$ in the genotype $\mathrm{P}^{-1} 6-4$ against the 213.40 capsules plant ${ }^{-1}$ in commercial check variety Ilsi-90. Genotype $\mathrm{L}^{-1} 0$ surpassed the commercial check for this trait and L-8 was at par with the commercial check. The seed index value (1000 seeds weight) was significantly maximum in the genotype $\mathrm{P}^{-1} 6-4$ (5.16 g), while the minimum seed index value was recorded in genotype L-53 (4.57 g) against $5.16 \mathrm{~g}$ seed index value in commercial check Ilsi-90. None of the genotypes could surpass commercial check variety for seed index, but the genotype was at par with the commercial check. Genotypes $11^{-1} 06$, Hala-3 and Summit also showed promising performance regarding the seed index.

The seed yield plant ${ }^{-1}$ was significantly $(P<0.05)$ higher in genotypes $\mathrm{P}^{-1} 6-4(1.28 \mathrm{~g})$, Summit $(1.28 \mathrm{~g})$, Ha- 
la-3 (1.27 g) and L-53 (1.26 g) against 0.71 g seed yield plant ${ }^{-1}$ in commercial check Ilsi-90; while the lowest seed yield plant ${ }^{-1}(0.48 \mathrm{~g})$ was obtained in case of genotype $11^{-1} 06$. Genotypes $\mathrm{P}^{-1} 6-4$, Summit, Hala-3, L-53, $\mathrm{L}^{-1} 0$ and L-8 surpassed the commercial check in seed yield plant ${ }^{-1}$. The seed yield plot $^{-1}$ was significantly $(P<$ $0.05)$ highest in genotypes $\mathrm{P}^{-1} 6-4(0.81 \mathrm{~kg})$ and the lowest seed yield plot $^{-1}$ was obtained in the genotype Shikarpur-2 $(0.55 \mathrm{~kg})$ against seed yield plot $^{-1}$ of $0.50 \mathrm{~kg}$ in commercial check variety Ilsi-90. This indicates that all genotypes tested in this experiment such as L-53, C-W-2, Shikarpur 2, $\mathrm{P}^{-1} 6-4$, L-8, $11^{-1} 06$, Hala 3 , $\mathrm{L}^{-1} 7$, Santane, Summit, $\mathrm{L}^{-1} 0$ surpassed the commercial check variety Ilsi-90 for seed yield $\mathrm{plot}^{-1}$. It can be clearly noticed from the agronomic performance of the new genotypes that these varieties possess the potential to become future varieties for general cultivation in Sindh province.

\subsection{Character Association (r)}

\subsubsection{Plant Height v/s Primary Branches Plant ${ }^{-1}$}

Plant height and number of primary branches plant ${ }^{-1}$ were positively but non-significantly $(P>0.05)$ correlated $\left(r=0.0 .1164^{\mathrm{NS}}\right)$ with each other, revealing that with the increase in plant height.

\subsubsection{Plant Height v/s Number of Capsules Plant ${ }^{-1}$}

The association between plant height and the number of capsules plant ${ }^{-1}$ suggested negative and non-significant correlation $\left(\mathrm{r}=-0.2587^{\mathrm{NS}}\right)$, referring a decrease in the number of capsules plant ${ }^{-1}$ with increasing plant height (Table 5).

\subsubsection{Plant Height v/s Number of Seeds Capsule ${ }^{-1}$}

Plant height and number of seeds capsule ${ }^{-1}$ were positively but non-significantly $(P>0.05)$ correlated with each other $\left(r=0.2804^{\mathrm{NS}}\right)$ with each other, suggesting that with the increase in plant height.

\subsubsection{Plant Height v/s Days to $75 \%$ Flowering}

There was a positive and non-significant $\left(r=0.3093^{\mathrm{NS}}\right)$ correlation between the plant height and days to flowering, which indicated that with increasing the days to flowering in linseed.

\subsubsection{Plant Height v/s Days to 90\% Maturity}

Interrelationship between plant height and number of days to maturity was non-significant $\left(r=0.1248^{\mathrm{NS}}\right)$ and positive. It means as the days to maturity increased, there was a negligible positive influence on the plant height of linseed.

\subsubsection{Plant Height $v / s$ Seed Index}

It is evident from the results (Table 5) that correlation between plant height and seed index was non-significant and negative $\left(\mathrm{r}=-0.0628^{\mathrm{NS}}\right)$.

\subsubsection{Plant Height v/s Yield Plant ${ }^{-1}$}

There was non-significant $(P>0.05)$ and negative association between plant height and seed yield plant ${ }^{-1}(\mathrm{r}=$ $-0.1353^{\mathrm{NS}}$ ).

\subsubsection{Plant height v/s Seed Yield Plot $^{-1}$}

Plant height and seed yield plot $^{-1}$ interrelationship revealed negative and non-significant correlation $(\mathrm{r}=$ $\left.-0.0001^{\mathrm{NS}}\right)$.

\subsubsection{Primary Branches Plant $\mathrm{t}^{-1} \mathrm{v} / \mathrm{s}$ Capsules Plant $\mathrm{t}^{-1}$}

Correlation between primary branches plant ${ }^{-1}$ and capsules plant ${ }^{-1}$ showed negative and non-significant $(P>$ $0.05)$ association $\left(\mathrm{r}=-0.0356^{\mathrm{NS}}\right)$.

\subsubsection{Primary Branches Plant ${ }^{-1}$ v/s Seeds Capsule ${ }^{-1}$}

Interrelationship of primary branches plant ${ }^{-1}$ with seeds capsule ${ }^{-1}$ showed positive but non-significant correlation $\left(r=0.2087^{\mathrm{NS}}\right)$. 


\subsubsection{Primary Branches Plant-1 v/s Days to Flowering}

These two traits were positively but non-significantly $(P>0.01)$ correlated with each other $\left(r=0.0490^{\mathrm{NS}}\right)$.

\subsubsection{Primary Branches Plant ${ }^{-1} \mathrm{v} / \mathrm{s}$ Days to Maturity}

The association of primary branches plant ${ }^{-1}$ and days to maturity was calculated and it was observed that correlation between primary branches plant $^{-1}$ and days to maturity was negative and significant $\left(\mathrm{r}=-0.368^{*}\right)$.

\subsubsection{Primary Branches Plant-1 v/s Seed Index}

The primary branches plant ${ }^{-1}$ and seed index revealed positive and non-significant $(P>0.05)$ correlation with each other $\left(r=0.2744^{\mathrm{NS}}\right)$.

\subsubsection{Primary Branches Plant ${ }^{-1} \mathrm{v} / \mathrm{s}$ Seed Yield Plant ${ }^{-1}$}

The correlation coefficient revealing relationship of primary branches plant ${ }^{-1}$ with seed yield plant ${ }^{-1}$ was positive and significant $\left(\mathrm{r}=0.3334^{*}\right)$.

\subsubsection{Primary Branches Plant ${ }^{-1} \mathrm{v} / \mathrm{s}$ Seed Yield Plot $^{-1}$}

The data in relation to correlation coefficient indicated that primary branches plant ${ }^{-1}$ had positive but nonsignificant $(P>0.05)$ correlation with seed yield $\operatorname{plot}^{-1}\left(r=0.2428^{\mathrm{NS}}\right)$.

\subsubsection{Capsules Plant ${ }^{-1}$ v/s Seeds Capsule ${ }^{-1}$}

The correlation coefficient indicated non-significant $(P>0.05)$ and negative correlation $\left(\mathrm{r}=-0.0304^{\mathrm{NS}}\right)$ between capsules plant ${ }^{-1}$ and seeds capsule ${ }^{-1}$.

\subsubsection{Capsules Plant ${ }^{-1} \mathrm{v} / \mathrm{s}$ Days to Flowering}

The correlation coefficient indicates positive and non-significant $(P>0.05)$ correlation $\left(\mathrm{r}=0.0451^{\mathrm{NS}}\right)$ between capsules plant ${ }^{-1}$ and days to flowering.

\subsubsection{Capsules Plant ${ }^{-1} \mathrm{v} / \mathrm{s}$ Days to Maturity}

There was a negative and non-significant $(P<0.05)$ correlation $\left(r=-0.0833^{\mathrm{NS}}\right)$ between the capsules plant ${ }^{-1}$ and days to maturity (Table 5).

\subsubsection{Capsules Plant ${ }^{-1} \mathrm{v} / \mathrm{s}$ Seed Index}

The data in relation to correlation coefficient indicated that seed index had positive but non-significant $(P>0.05)$ correlation with seed index $\left(r=0.0747^{\mathrm{NS}}\right)$.

\subsubsection{Capsules Plant ${ }^{-1} \mathrm{v} / \mathrm{s}$ Seed Yield Plant ${ }^{-1}$}

The correlation coefficient indicates non-significant $(P>0.05)$ but positive correlation $\left(r=0.2605^{\mathrm{NS}}\right)$ between capsules plant ${ }^{-1}$ and seed yield plant ${ }^{-1}$.

\subsubsection{Seeds Capsule ${ }^{-1} \mathrm{v} / \mathrm{s}$ Days to Flowering}

There was a negative but non-significant $(P>0.05)$ association $\left(\mathrm{r}=-0.2795^{\mathrm{NS}}\right)$ between the seeds capsule $\mathrm{e}^{-1}$ and days to flowering (Table 5).

\subsubsection{Capsules Plant ${ }^{-1} \mathrm{v} / \mathrm{s}$ Days to Maturity}

The correlation of coefficient $\left(\mathrm{r}=-0.3567^{*}\right)$ between the capsules plant ${ }^{-1}$ and the number of days to maturity described that with increase in the days to maturity, the capsules plant ${ }^{-1}$ were negatively influenced (Table 5).

\subsubsection{Seeds Capsule ${ }^{-1} \mathrm{v} / \mathrm{s}$ Seed Index}

The correlation coefficient indicates non-significant $(P>0.05)$ positive correlation $\left(\mathrm{r}=0.0609^{\mathrm{NS}}\right)$ between seeds capsule $^{-1}$ and seed index which indicated that with the increase in the seeds capsule ${ }^{-1}$ no pronounced effect on seed index was recorded. 
3.2.24. Days to Maturity v/s Spike Length

The correlation coefficient describes positive and significant $(P<0.05)$ correlation $\left(r=0.5384^{* *}\right)$ between seeds capsul $^{-1}$ and seed yield plant ${ }^{-1}$, which indicated that with increase in seeds capsule ${ }^{-1}$, the significant increase in seed yield plant ${ }^{-1}$ was recorded.

\subsubsection{Seeds Capsule ${ }^{-1} \mathrm{v} / \mathrm{s}$ Seed Yield Plot $^{-1}$}

There was a positive but non-significant $(P>0.05)$ correlation $\left(r=0.0065^{\mathrm{NS}}\right)$ between the seeds capsule $\mathrm{e}^{-1}$ and seed yield plot $^{-1}$, which showed that with increasing the seeds capsule ${ }^{-1}$, no pronounced effect on seed yield plot $^{-1}$ was observed (Table 5).

\subsubsection{Days to $75 \%$ Flowering v/s Days to $90 \%$ Maturity}

The data in relation to correlation coefficient indicated that days to $7 \% \%$ flowering had positive and significant $(P<0.05)$ correlation with days to $90 \%$ maturity $\left(r=0.4073^{* *}\right)$. This association shows that with increase in days to $75 \%$ flowering, the number of days to maturity increased simultaneously.

\subsubsection{Days to $75 \%$ Flowering v/s Seed Index}

The correlation coefficient indicates significant $(P<0.05)$ and positive correlation $\left(\mathrm{r}=0.4291^{* *}\right)$ between days to $75 \%$ flowering and seed index suggested that increase in days to flowering of linseed genotypes.

\subsubsection{Days to $75 \%$ Flowering v/s Seed Yield Plant ${ }^{-1}$}

There was a non-significant $(P>0.05)$ but positive correlation $\left(r=0.3076^{\mathrm{NS}}\right)$ between the days to $75 \%$ flowering and seed yield plant ${ }^{-1}$ (Table 5).

\subsubsection{Days to $75 \%$ Flowering v/s Seed Yield Plot $^{-1}$}

The interrelationship between days to $75 \%$ flowering and seed yield plot $^{-1}$ of linseed genotypes showed a positive but non-significant $(P>0.05)$ correlation $\left(\mathrm{r}=0.0949^{\mathrm{NS}}\right)$, which suggested that with increase in the days to $75 \%$ flowering, the seed yield plot $^{-1}$ was not affected (Table 5).

\subsubsection{Days to Grain Filling v/s Spike Length}

The correlation coefficient indicates significant $(P<0.05)$ and positive correlation $\left(\mathrm{r}=0.3973^{* *}\right)$ between days to $90 \%$ maturity and seed index which revealed that with the increase in the days to $90 \%$ maturity, a remarkable increase in seed index is expected.

\subsubsection{Days to $90 \%$ Maturity v/s Seed Yield Plant ${ }^{-1}$}

The correlation coefficient indicates negative and significant $(P<0.05)$ correlation $\left(\mathrm{r}=-0.4156^{* *}\right)$ between days to $90 \%$ maturity and seed yield plant ${ }^{-1}$, which showed that with increase in days to maturity, the seed yield plant $^{-1}$ was decreased significantly.

\subsubsection{Days to $90 \%$ Maturity v/s Seed Yield Plot ${ }^{-1}$}

There was a negative and significant $(P<0.05)$ correlation $\left(r=-0.3423^{*}\right)$ between the days to $90 \%$ maturity and seed yield plot $^{-1}$, which indicated that with increasing the days to maturity.

\subsubsection{Seed Index v/s Seed Yield Plant ${ }^{-1}$}

The data in relation to correlation coefficient indicated that seed index had positive but non-significant $(P>0.05)$ correlation with seed yield plant ${ }^{-1}\left(r=0.1837^{\mathrm{NS}}\right)$.

\subsubsection{Seed Index v/s Seed Yield Plant ${ }^{-1}$}

The correlation coefficient indicates significant $(P>0.05)$ and positive correlation $\left(\mathrm{r}=0.5160^{* *}\right)$ between seed index and seed yield plot $^{-1}$ suggesting that increase in seed index value caused positive change in seed yield plot $^{-1}$.

\subsubsection{Seed Yield Plant ${ }^{-1} \mathrm{v} / \mathrm{s}$ Seed Yield Plot $^{-1}$}

The association of seed yield plant ${ }^{-1}$ and seed yield plot $^{-1}$ was calculated and it was observed that correlation 
between seed yield plant ${ }^{-1}$ and seed yield plot $^{-1}$ was positive but non-significant $\left(\mathrm{r}=0.2890^{\mathrm{NS}}\right)$.

\section{Discussion}

Development of crop yield through improvement in individual plant traits are of considerable importance. In Pakistan, seed flaxes are cultivated for seed purposes from which oil extracted. Linseed oil is used in paints, varnishes and cloth and linoleum. The material remaining after extraction of fiber can be pulped for use in the manufacture of paper and straw board. Linseed has got a great economic value for the commercial utility of its oil and fibers. Its oil is used in local medicines as demulcent, emollient and laxative and is taken orally in bronchial infection and diarrhea. It is also used commercially in soap factories; In Pakistan among those, availability of new varieties is most important issue [4] [8], to improve crop yield, development of new varieties with high yields and more responsive to input application are needed [9], number of capsules per plant, number of seeds per capsule, 1000-seed weight and seed yield of flax cultivars differ significantly among varieties and apart from varieties these traits were improved with increasing input levels [10].

The analysis of variance suggested significant $(P<0.05)$ variation among linseed genotypes for all the traits studied in this experiment. Most of the genotypes attained flowering and maturity earlier than the check variety; while $\mathrm{P}^{-1} 6-4$ surpassed Ilsi-90 for primary branches; and most of the remaining genotypes were at par with the commercial check for primary branches. Genotype $\mathrm{L}^{-1} 0$ surpassed the commercial check for capsules plant ${ }^{-1}$ and L-8 was at par with the commercial check; while none of the genotypes could surpass commercial check variety for seed index, but $11^{-1} 06$, Hala- 3 and Summit also showed promising performance regarding the seed index. All the genotypes tested in this experiment such as L-53, C-W-2, Shikarpur 2, $\mathrm{P}^{-1} 6-4, \mathrm{~L}-8,11^{-1} 06$, Hala 3 , $\mathrm{L}^{-1}$, Santane, Summit, $\mathrm{L}^{-1} 0$ surpassed the commercial check variety Ilsi-90 for seed yield plot $^{-1}$.

Linseed genotypes developed through various breeding programs varied significantly $(P<0.05)$ for their agronomic performance \& improved with the development of new strains [8]-[11], Varieties are differ from each other in genetic make up for growth and yield, plants height and branches, capsules plant ${ }^{-1}$, seed, straw yields and oil yield differ significantly among genotypes [12] [13], revealed the biomass and net primary productivity were comparatively higher in cv. LC-54 than NP-5. Some other researchers revealed in their studies, it also varied from days to flowering, seed yield, plant height and branches plant ${ }^{-1}$ and also significant variation in genotypes and their characteristics [14]-[17] revealed that seed yields were highest in linseed cv. Jawahar-23 (1.61 $\left.\mathrm{t} \mathrm{ha}^{-1}\right)$ followed by RLC ${ }^{-1}\left(1.51 \mathrm{t} \mathrm{ha}^{-1}\right)$, RLC-2 (1.42 $\left.\mathrm{t} \mathrm{ha}^{-1}\right)$ and T-397 (1.28 $\left.\mathrm{tha}^{-1}\right)$.

The present study further showed that the correlation coefficient for yield and its contributing traits of linseed genotypes was positive and significant $(P<0.05)$ for primary branches plant ${ }^{-1}$ vs seed yield plant ${ }^{-1}\left(r=0.3334^{*}\right)$, days to maturity vs spike length $\left(r=0.5384^{* *}\right)$, days to $75 \%$ flowering vs days to $90 \%$ maturity $\left(r=0.4073^{* *}\right)$, days to $75 \%$ flowering vs seed index $\left(r=0.4291^{* *}\right)$, days to $90 \%$ maturity vs seed index $\left(r=0.3973^{* *}\right)$ and seed index v/s seed yield $\operatorname{plot}^{-1}\left(r=0.5160^{* *}\right)$. Negative and significant $(P<0.05)$ association was observed for primary branches plant ${ }^{-1}$ vs days to maturity $\left(r=-0.368^{*}\right)$, capsules plant ${ }^{-1}$ vs days to maturity $\left(r=-0.3567^{*}\right)$, days to $90 \%$ maturity vs seed yield plant ${ }^{-1}\left(\mathrm{r}=-0.4156^{* *}\right)$ and days to $90 \%$ maturity vs seed yield plot $^{-1}(\mathrm{r}=$ $\left.-0.3423^{*}\right)$. These results are further supported by Jain et al. [18] who observed significant variation in ten yield related traits in 28 hybrids of linseed and reported that highest variability in varieties was observed for capsules plant $^{-1}$ which guided the change in yield plant ${ }^{-1}$ significantly. Khorgade and Pillai [19], revealed the seeds plant $^{-1}$, capsules plant ${ }^{-1}$, branches plant ${ }^{-1}$ and seeds capsule ${ }^{-1}$ was positively and significantly correlated with seed yield. Seeds plant ${ }^{-1}$ and capsules plant ${ }^{-1}$ showed a high positive direct effect on seed yield. They suggested that selection for seeds plant ${ }^{-1}$ and capsules plants ${ }^{-1}$ is important attributes to evolve high yielding varieties of linseed. Mishra et al. [20], revealed the plant height exhibited negative direct association with seed yield. Path analysis revealed that plant height had a low association with number of branches and capsules per plant. Pal et al. [21], also found that the number of days to $50 \%$ flowering, days to maturity number of primary branches plant $^{-1}$, number of capsules plant ${ }^{-1}$, number seeds capsule ${ }^{-1}, 1000$-seed weight had significant and positive correlation with seed yield plant ${ }^{-1}$. Chimurkar et al. [22], found that seed yield plant ${ }^{-1}$ was positively and significantly correlated with number of branches plant ${ }^{-1}$, number of capsules plant ${ }^{-1}$ and 1000 -seed weight but non-significantly and negatively correlated with plant height. Akbar et al. [23], also reported that the growth and yield parameters like plant height, number of branches plant ${ }^{-1}$, number of capsules plant ${ }^{-1}$, 1000-seed weight, biological yield, seed yield, straw yield and harvest index were influenced significantly under various interactions of row spacing and genotypes, Ali et al. [8] compared the production potential of Linola and the traditional 
oilseed linseed Chandni under different nitrogen levels were he found significant differences in different traits of linola and linseed (chandni). Khan et al. [24] revealed the differences in mean yield performance of 10 linseed genotypes were highly significant during 6 years indicating presence of sufficient amount of variation among the genotypes. Khan et al. [25] revealed the sowing date had significant effect on plant height, number of capsule in plant, seed yield, Biomass, oil percent and oil yield in $1 \%$ level and on number of seed in capsule in $5 \%$ level of linseed. Ghanbari-odivi et al. [26] also revealed the confirmed results of the complex genetic architecture of yield-related traits and the inherent difficulties associated with their identification while illustrating the potential for improvement through marker-assisted selection of linseed.

\section{Conclusions}

The screening of some selected linseed genotypes for yield performance as well as associations amongst yield and its contributing traits were carried out during the year 2013-14. The experimental material comprised of eleven new linseed genotypes and a commercial check (Ilsi). The linseed genotypes included: L-53, C-W-2, Shikarpur 2, $\mathrm{P}^{-1} 6-4, \mathrm{~L}-8,11^{-1} 06$, Hala 3, $\mathrm{L}^{-1}$, Santane, Summit, $\mathrm{L}^{-1} 0$ and llsi 90 (Check). The mean squares drawn from the analysis of variance and performance was analysed in regards to days to $75 \%$ flowering, days to 90\% maturity, plant height, primary branches plant ${ }^{-1}$, seeds capsule ${ }^{-1}$, capsules plant ${ }^{-1}, 1000$ seed weight, seed yield plant ${ }^{-1}$, seed yield plot ${ }^{-1}$. The findings of the study are summarized as follows:

The analysis of variance suggested significant $(P<0.05)$ variation among linseed genotypes for days to $75 \%$ flowering, days to $90 \%$ maturity, plant height, primary branches plant ${ }^{-1}$, seeds capsule ${ }^{-1}$, capsules plant ${ }^{-1}, 1000$ seed weight, seed yield plant ${ }^{-1}$ and seed yield plot ${ }^{-1}$. Linseed genotype L-8 took maximum days to $75 \%$ flowering (83.10) and minimum (77.84) by L-53 against 81.44 days by check variety Ilsi-90. Genotype $11^{-1} 06$ took more days to $90 \%$ maturity (118.10) and minimum (112.27) by L-53 against 117.73 days in Ilsi-90. The number of primary branches plant ${ }^{-1}$ was highest (33.00) in genotype $\mathrm{P}^{-1} 6-4$ and the lowest (23.07) in Shikarpur-2 against 30.73 branches in Ilsi-90. More seeds capsule ${ }^{-1}$ were noted in genotypes L-8 (9.67), L-53 (9.58), Hala-3 (9.51) and $\mathrm{L}^{-1} 0$ (9.15); and lowest in C-W-2 (8.20) against 8.55 seeds capsule ${ }^{-1}$ in Ilsi-90.

The capsules plant ${ }^{-1}$ was highest (221.07) in genotype $\mathrm{L}^{-1} 0$ and lowest (196.27) in $\mathrm{P}^{-1} 6-4$ against 213.40 in Ilsi-90. The seed index was highest in genotype $\mathrm{P}^{-1} 6-4$ (5.16 g) and minimum in genotype L-53 (4.57 g) against $5.16 \mathrm{~g}$ seed index in Ilsi-90. The seed yield plant ${ }^{-1}$ was higher in genotypes $\mathrm{P}^{-1} 6-4(1.28 \mathrm{~g})$, Summit $(1.28 \mathrm{~g})$, Hala-3 $(1.27 \mathrm{~g})$ and L-53 (1.26 g) against $0.71 \mathrm{~g}^{-1}$ seed yield plant ${ }^{-1}$ in Ilsi-90 and lowest $(0.48 \mathrm{~g})$ in $11^{-1} 06$. The seed yield plot ${ }^{-1}$ was highest in genotypes $\mathrm{P}^{-1} 6-4(0.81 \mathrm{~kg})$ and lowest in Shikarpur-2 $(0.55 \mathrm{~kg})$ against $0.50 \mathrm{~kg}$ in Ilsi-90. This indicates that all the genotypes tested in this experiment such as L-53, C-W-2, Shikarpur 2, $\mathrm{P}^{-1} 6-4$, L-8, $11^{-1} 06$, Hala 3, $\mathrm{L}^{-1} 7$, Santane, Summit, $\mathrm{L}^{-1} 0$ surpassed the commercial check variety Ilsi-90 for seed yield plot $^{-1}$. It can be clearly noticed from the agronomic performance of the new genotypes that these varieties possess the potential to become future varieties for general cultivation in Sindh province.

The correlation coefficient for yield and its contributing traits of linseed genotypes showed a positive and significant $(P<0.05)$ association for primary branches plant ${ }^{-1}$ vs seed yield plant ${ }^{-1}\left(\mathrm{r}=0.3334^{*}\right)$, days to maturity vs spike length $\left(r=0.5384^{* *}\right)$, days to $75 \%$ flowering vs days to $90 \%$ maturity $\left(r=0.4073^{* *}\right)$, days to $75 \%$ flowering vs seed index $\left(r=0.4291^{* * *}\right)$, days to $90 \%$ maturity vs seed index $\left(r=0.3973^{* * *}\right)$ and seed index v/s seed yield $\operatorname{plot}^{-1}\left(r=0.5160^{* *}\right)$. Negative and significant $(P<0.05)$ association was observed for primary branches plant ${ }^{-1}$ vs days to maturity $\left(r=-0.368^{*}\right)$, capsules plant ${ }^{-1}$ vs days to maturity $\left(r=-0.3567^{*}\right)$, days to $90 \%$ maturity vs seed yield plant ${ }^{-1}\left(\mathrm{r}=-0.4156^{* *}\right)$ and days to $90 \%$ maturity vs seed yield $\operatorname{plot}^{-1}\left(\mathrm{r}=-0.3423^{*}\right)$.

Non-significant and positive $(P>0.05)$ association was calculated for plant height vs primary branches plant $^{-1}\left(r=0.0 .1164^{\mathrm{NS}}\right)$, Plant height vs number of seeds capsule ${ }^{-1}\left(\mathrm{r}=0.2804^{\mathrm{NS}}\right)$, Plant height vs days to $75 \%$ flowering $\left(r=0.3093^{\mathrm{NS}}\right)$, Plant height vs days to $90 \%$ maturity $\left(r=0.1248^{\mathrm{NS}}\right)$, Primary branches plant ${ }^{-1}$ vs seeds capsule $^{-1}\left(r=0.2087^{\mathrm{NS}}\right)$, Primary branches plant ${ }^{-1}$ vs days to flowering $\left(\mathrm{r}=0.0490^{\mathrm{NS}}\right)$, Primary branches plant ${ }^{-1}$ vs seed index $\left(r=0.2744^{\mathrm{NS}}\right)$, Primary branches plant ${ }^{-1}$ vs Seed yield $\operatorname{plot}^{-1}\left(\mathrm{r}=0.2428^{\mathrm{NS}}\right)$, capsules plant ${ }^{-1}$ vs days to flowering $\left(r=0.0451^{\mathrm{NS}}\right)$, capsules plant ${ }^{-1}$ vs seed index $\left(\mathrm{r}=0.0747^{\mathrm{NS}}\right)$, Capsules plant ${ }^{-1}$ vs Seed yield plant $^{-1}\left(r=0.2605^{\mathrm{NS}}\right)$, Seeds capsule ${ }^{-1}$ vs Days to flowering $\left(\mathrm{r}=-0.2795^{\mathrm{NS}}\right)$, Seeds capsule ${ }^{-1}$ vs seed index $(\mathrm{r}=$ $\left.0.0609^{\mathrm{NS}}\right)$, Seeds capsule ${ }^{-1}$ vs Seed yield $\operatorname{plot}^{-1}\left(\mathrm{r}=0.0065^{\mathrm{NS}}\right)$, Days to $75 \%$ flowering vs seed yield plant ${ }^{-1}(\mathrm{r}=$ $\left.0.3076^{\mathrm{NS}}\right)$, Days to $75 \%$ flowering vs seed yield $\operatorname{plot}^{-1}\left(\mathrm{r}=0.0949^{\mathrm{NS}}\right)$, Seed index vs seed yield plant ${ }^{-1}(\mathrm{r}=$ $\left.0.1837^{\mathrm{NS}}\right)$, Seed yield plant ${ }^{-1}$ vs seed yield $\operatorname{plot}^{-1}\left(\mathrm{r}=0.2890^{\mathrm{NS}}\right)$.

Non-significant and negative $(P>0.05)$ association was observed for Plant height vs number of capsules plant $^{-1}\left(\mathrm{r}=-0.2587^{\mathrm{NS}}\right)$, Plant height vs seed index $\left(\mathrm{r}=-0.0628^{\mathrm{NS}}\right)$, Plant height vs Yield plant ${ }^{-1}\left(\mathrm{r}=-0.1353^{\mathrm{NS}}\right)$, 
Plant height vs seed yield $\operatorname{plot}^{-1}\left(\mathrm{r}=-0.0001^{\mathrm{NS}}\right)$, Primary branches plant ${ }^{-1}$ vs capsules plant $^{-1}\left(\mathrm{r}=-0.0356^{\mathrm{NS}}\right)$, Capsules plant $^{-1}$ vs Seeds capsule ${ }^{-1}\left(r=-0.0304^{\mathrm{NS}}\right)$, Capsules plant ${ }^{-1}$ vs days to maturity $\left(\mathrm{r}=-0.0833^{\mathrm{NS}}\right)$ and Seeds capsule ${ }^{-1}$ vs Days to flowering $\left(r=-0.2795^{\mathrm{NS}}\right)$.

\section{References}

[1] Thompson, L.U., Chen, J.M., Li, T., Weippl, K.S. and Goss, P.E. (2005) Dietary Flaxseed Alters Tumor Biological Markers in Postmenopausal Breast Cancer. Clinical Cancer Research, 11, 3828-3835. http://dx.doi.org/10.1158/1078-0432.CCR-04-2326

[2] Leilah, A.A. (1993) Evaluation of Yield and Its Components of Flax Cultivars under Different Nitrogen Fertilizer Levels. Journal of Agricultural Science, Mansoura University, 18, 313-321.

[3] Hatim, M. and Abbasi, G.Q. (1994) Oil Seed Crops. In: Crop Production, National Book Foundation, Islamabad. 366-369.

[4] Shafi, N. (1994) Crop Production. National Book Foundation, Islamabad, 366-367.

[5] Gomez, K.A. and Gomez, A.A. (1984) Statistical Procedures for Agricultural Research. 2nd Edition, John Wiley and sons, New York, 680 p.

[6] Dewey, D. and Lu, K.M. (1959) Correlation and Path Coefficient and Path Coefficient Analysis of Components of Crested Wheat Gross Production. Agronomy Journal, 51, 515-518. http://dx.doi.org/10.2134/agronj1959.00021962005100090002x

[7] Snedecor, W.G. and Cochran, W.G. (1980) Statistical Methods. Seventh Edition, The IOWA State University Press, Ames, IA. Agriculture and Forestry.

[8] Ali, S., Cheema, M.A., Wahid, M.A., Sattar, A. and Saleem, M.F. (2011) Comparative Production Potential of Linola and Linseed under Different Nitrogen Levels. Crop \& Environment, 2, 33-36.

[9] Fageria, N.K. and Baligar, V.C. (2005) Enhancing Nitrogen Use Efficiency in Crop Plants. Advances in Agronomy, 88, 97-185. http://dx.doi.org/10.1016/S0065-2113(05)88004-6

[10] Hussain, M.M.M. and Zedan, S.Z.A. (2008) Yield and Quality of Two Flax Varieties as Affected by Foliar Spraying with Potassium Rates and Nitrogen Levels under Sandy Soil Condition. Journal of Agricultural Science, Mansoura University, 33, 3937-3952.

[11] Nandhogopal, A., Subramanian, K.S. and Ali, A.M. (1993) Response of Sunflower Genotypes for Nitrogen Application. New Botanist, 20, 87-92.

[12] Vender, C., Natarelli, L., Maestrini, C. and Cremachi, D. (1995) Effect of Husbandry Practices on Some Biological and Agronomic Characteristics of a Linseed Cultivar. Terra e Sole, 50, 35-39.

[13] Pandey, D.D., Chanchal, S. and Singh, N.K. (2002) Biomass and Net Primary Productivity of Linum usitatissimum L. Journal of Environment and Ecology, 20, 555-557.

[14] Khare, J.P., Sharma, R.S. and Dubey, M.P. (1996) Effect of Row Spacing and Nitrogen on Rainfed Linseed (Linum usitatissimum). Indian Journal of Agronomy, 41, 116-118.

[15] Singh, D.N. (2001) Heritability and Genetic Advance in Linseed (Linum usitatissimum L.). Journal of Research, Birsa Agricultural University, 13, 73-74.

[16] Sharma, A. and Hunsigi, G. (1996) Performance of Two Linseed Genotypes at Different Spacings and Nitrogen Levels under Irrigated Conditions. Karnataka Journal of Agricultural Sciences, 9, 16-20.

[17] Rennebaum, H., Grimm, E., Warnstorff, K. and Diepenbrock, W. (2002) Fibre Quality of Linseed (Linum usitatissimum L.) and the Assessment of Genotypes for Use of Fibre as a Byproduct. Industrial Crops and Products, 16, 201-215. http://dx.doi.org/10.1016/S0926-6690(02)00048-1

[18] Jain, H.C., Jain, K.K. and Deshmukh, R.M. (1995) Performance of Linseed Varieties at Different Seed Rates and Row Spacings under Rainfed Conditions. Advances in Agric. Res. India, 4, 53-58.

[19] Khorgade, P.W. and Pillai (1994) Genetic Variability Studies in Linseed. Agricultural Science Digest, 14, 54-56.

[20] Mishra, A.K. and Yadav, L.N. (1999) Genetic Parameters and Association Analysis in Linseed. Indian Journal of Agricultural Research, 33, 113-118.

[21] Pal, S.S., Gupta, T.R. and Sindh, I. (2000) Genetic Determination of Yield Linseed (Linum usitatissimum L). Crop Improvement, 27, 109-110.

[22] Chimurkar, H.C., Patil, S. and Rathod, D.R. (2001) Character Association Studies in Linseed (Linum usitatissimum L). Annals of Plant Physiology, 15, 72-76.

[23] Akbar, M., Mahmood, T., Anwar, M., Ali, M., Shafiq, M. and Salim, J. (2003) Linseed Improvement through Genetic Variability, Correlation and Path Coefficient Analysis. International Journal of Agriculture and Biology, 5, 303-305. 
[24] Khan, M.B., Yasir, T.A. and Aman, M. (2005) Growth and Yield Comparison of Different Linseed (Linum usitatissimum L.) Genotypes Planted at Different Row Spacing. International Journal of Agriculture and Biology, 7, 515-517.

[25] Khan, M.A., Akmal, M., Mirza, M.Y. and Mohmand, A.S. (2011) Performance of Linseed Genotypes for Seed Yield and Stability Analysis at NARC Islamabad. Pakistan Journal of Agricultural Research, 2, 1-4.

[26] Ghanbari-odivi, A., Safari, A., Tahmasebi, B.K., Farrokhi, M. and Bahrampour, B. (2013) Effect of Delaying in Sowing Date on Growth, Yield, Yield Components and Oil Content of Two Genotypes of Flaxseed (Linum usitatissimum L). Advances in Environmental Biology, 7, 1014-1018. 